Електронне наукове фахове видання "Ефективна економіка" включено до переліку наукових фахових видань України з питань економіки

(Наказ Міністерства освіти і науки України від 11.07.2019 № 975) www. economy.nayka.com. ua | № 11, 2019|28.11.2019 p.

DOI: $10.32702 / 2307-2105-2019.11 .89$

УДК 657.1

Т. В. Польова,

к. е. н., доцент, доцент кафедри економіки та обліку Харківського торговельноекономічного інституту КНТЕУ

ORCID: 0000-0003-2198-7396

А. В. Дружина, магістр Харківського торговельно-економічного інституту КНТЕУ

ORCID: 0000-0003-2440-6817

\title{
ФІНАНСОВА ЗВІТНІСТЬ ЯК ЕЛЕМЕНТ СИСТЕМИ УПРАВЛІННЯ ПІДПРИЕМСТВОМ
}

\author{
T. V. Poleva \\ Ph.D., Associate Professor, Associate Professor Department of Economics and Accounting, \\ Kharkiv Trade and Economic Institute, KNTEU \\ A.V. Druguna \\ Master of Kharkov Trade and Economic Institute of KNTEU
}

\section{FINANCIAL STATEMENTS AS AN ELEMENT OF THE ENTERPRISE MANAGEMENT SYSTEM}

У статті визначено фінансову звітність як однин із основоположних елементів облікової системи та системи управління підприємством. Зазначено, що основною метою складання фінансової звітності є надання користувачам правдивої, повної та неупередженої інформації. Визначено, що елементами поданої системи управління підприємством є блок інформаційного забезпечення, який, в свою чергу складається $з$ планування, обліку та аналізу, які взаємодіють між собою через інформаиійні потоки, формуючи потужну базу даних для прийняття рішень $i$ здійснення контролю; та з блоку сфери прийняття управлінських рімень, де саме і знаходиться елемент - фінансова звітність. Наведено компоненти фінансової звітності, які відображають різні аспекти господарських операиій $і$ подій за звітний період, відповідну інформацію попереднього звітного періоду та розкриття облікової політики та ї̈ змінах, що робить можливим ретроспективний та перспективний аналіз діяльності підприємства для подальшого прийняття управлінських рішень.

It is noted that the successful activity of the enterprise depends to a great extent on the quality, reliability, completeness and impartiality of the information received, both about the internal state of the enterprise and external changes in the conditions of activity. The main source of information is financial reporting. The information presented in the financial statements of the company allows you to develop the necessary measures and procedures aimed at survival of the company in a competitive environment, preventing bankruptcy and financial failure, leadership in the fight against competitors, increasing the economic potential of the company, maximizing profits and minimizing costs, ensuring cost-effective work of the enterprise. 
The article identifies financial statements as one of the fundamental elements of accounting and enterprise management systems. It is stated that the primary purpose of financial statements is to provide users with truthful, complete and impartial information. It is determined that the elements of the submitted enterprise management system are a block of information support, which in turn consists of planning, accounting and analysis, which interact with each other through information flows, forming a powerful database for decision-making and control; and from the block of management decision-making where the financial reporting element is. The factors that influence the level of information support are identified and characterized, namely external (circle of external users; level of disclosure of information to meet information needs of external users) and internal (size of enterprise and scale of activity; structure of management apparatus; information needs of users; qualification level of employees accounting and analytical units; level of detail and generalization of information; frequency of information submission). The components of the financial statements are presented, which reflect various aspects of business transactions and events during the reporting period, relevant information of the previous reporting period and disclosure of accounting policies and its changes, which makes it possible to retrospective and prospective analysis of the enterprise's activities for further management decisions.

Ключові слова: фінансова звітність, інформаційне забезпечення, користувачі фінансової звітності, управління підприємством.

Keywords: financial reporting, information support, users of financial statements, enterprise management.

Постановка проблеми у загальному вигляді. Успішна діяльність підприємства в значній мірі залежить від якості, достовірності, повноти й неупередженості отримуваної інформації як про внутрішній стан підприємства, так і про зовнішні зміни умов діяльності. Головним джерелом інформації виступає фінансова звітність.

Інформація, яка викладена в фінансовій звітності підприємства, дозволяє виробити необхідні заходи i процедури, спрямовані на виживання підприємства в умовах конкурентної боротьби, запобігання банкрутства і фінансових невдач, лідерство в боротьбі з конкурентами, ріст економічного потенціалу підприємства, максимізацію прибутку і мінімізацію витрат, забезпечення рентабельної роботи підприємства.

Неточності у фінансовій звітності призводять до помилок у прийнятті управлінських рішень користувачами інформації, а в кінцевому рахунку - до зниження ефективності діяльності підприємств і, відповідно, рівня їх прибутковості.

Дослідження проблем і перспектив фінансової звітності актуальне й важливе в сучасних умовах господарювання, оскільки належне ведення обліку та єдиний порядок підготовки та подання фінансової звітності сприятимуть уніфікації вихідної інформації, єдиному розумінню звітних показників зовнішніми, в тому числі зарубіжними, користувачами.

Аналіз останніх досліджень та публікацій. Бухгалтерська звітність завжди перебувала i перебуватиме у центрі уваги науковців і практиків, оскільки вона дуже важлива для прийняття управлінських рішень і $є$ кінцевим продуктом бухгалтерського обліку. Вагомий внесок у розробку теоретичних, організаційно-методичних та методологічних положень щодо процесу складання фінансової звітності та його удосконалення здійснили такі відомі вітчизняні науковці, як М. І. Бондар, Л.М. Біла, Ю. А. Верига, М. В. Корягін, П. О. Куцик, В. В. Рєзникова, Н.В. Семенишена, В. Ю. Світлична та інші.

Метою статті $\epsilon$ визначення проблемних аспектів та ролі фінансової звітності в сучасних умовах господарювання і перспектив їі розвитку.

Виклад основного матеріалу.

Загальновідомо, що бухгалтерська фінансова звітність підприємства являє собою систему узагальнених показників, які характеризують підсумки виробничої та фінансово-господарської діяльності підприємства, що здійснюється шляхом складання звітності за звітний період (місяць, квартал, рік). При проведенні досліджень зроблено висновок, що наведені в наукових джерелах дефініції категорії «звітність» переконують в тому, що практично всі науковці одностайно вважають ії системою показників.

Не зовсім точним $є$ також тлумачення звітності як системи показників, що характеризує фінансовий та майновий стан підприємства та бухгалтерської звітності, що відображає фінансовий та майновий стан підприємства і результати діяльності.

Дефініції фінансової звітності також різняться в науковій літературі. 
Так, Біла Л.М. визначила поняття «фінансова звітність» як сукупність форм згрупованої та узагальненої інформації, що розкриває фінансовий стан і результати діяльності підприємства за звітний період [1].

На сучасному етапі поняття «бухгалтерська звітність» все більше витісняється, однак можна відзначити наявність принаймні трьох позицій науковців: поняття «бухгалтерська звітність» і «фінансова звітність» ототожнюються; «бухгалтерська звітність» і «фінансова звітність» - різні поняття, «фінансова звітність» - складова частина бухгалтерської.

Поняття «фінансова звітність» у вітчизняному термінологічному фонді знайшло відображення у Законі України «Про бухгалтерський облік і фінансову звітність в Україні», який визначає фінансову звітність як бухгалтерську звітність, що містить інформацію про фінансове становище, результати діяльності та рух грошових коштів підприємства за звітний період [2].

На думку Семенишеної Н.В., багатозначність тлумачення цього терміну очевидна, оскільки за цим визначенням i статистична, i фінансова, i податкова, а також внутрішньогосподарська звітність $\epsilon$ складовими частинами бухгалтерської звітності [3] і вказує на те, що неоднозначність тлумачення викривлює сутність бухгалтерської звітності і, як елементу методу і як завершальної стадії бухгалтерського обліку, власне, як практичної діяльності.

У своїх дослідженнях автор дала більш точне визначення поняття «звітність», як сукупності узагальнених показників, формалізованих законодавством або організацією, які характеризують ефективність функціонування організації (або окремих ії елементів) за визначений період [4].

Національне положення (стандарт) бухгалтерського обліку 1 «Загальні вимоги до фінансової звітності» визначає дану дефініцію наступним чином : «бухгалтерська звітність, що містить інформацію про фінансовий стан, результати діяльності та рух грошових коштів підприємства за звітний період» [5]. При цьому, будь-яке підприємство, складаючи та подаючи фінансову звітність, переслідує певну мету - $є$ надати будь-якому користувачу повну, правдиву й неупереджену інформацію щодо фінансового стану, результатів господарської діяльності підприємства та руху його коштів.

3 урахуванням інформаційного змісту даних, відображених у звітності, остання займає особливе місце в бухгалтерському обліку, який є складовою системи управління підприємством

Узагальнення поглядів вчених дозволило визначити місце елементів фінансової звітності в рамках системи управління підприємством (рис. 1). 


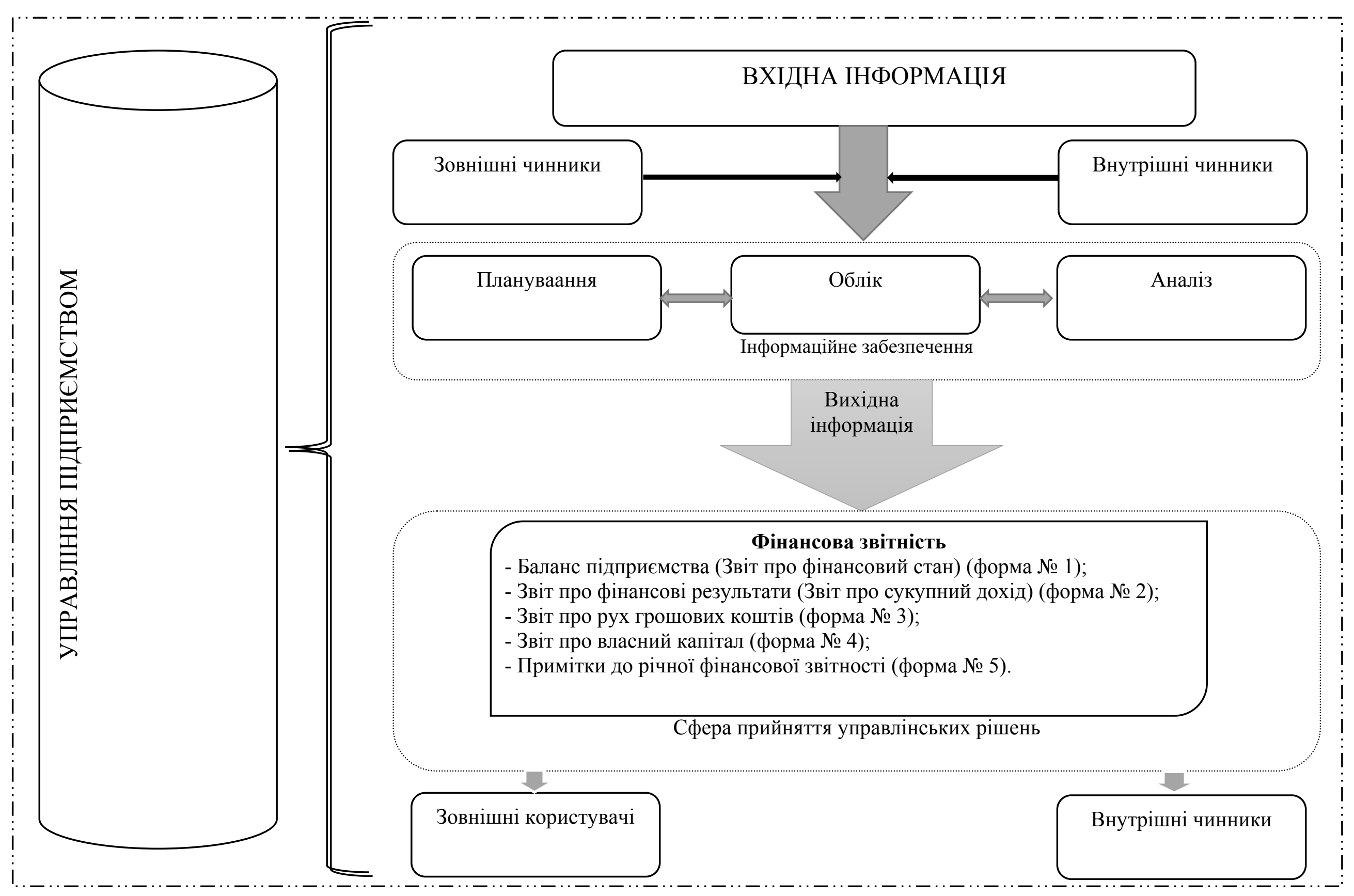

Рис. 1. Місце фінансової звітності серед елементів в системі управління підприємством 
Відповідно, елементами поданої системи управління підприємством $є$ блок інформаційного забезпечення, який, в свою чергу складається з планування, обліку та аналізу, які взаємодіють між собою через інформаційні потоки, формуючи потужну базу даних для прийняття рішень і здійснення контролю; та 3 блоку сфери прийняття управлінських рішень, де саме і знаходиться елемент - фінансова звітність.

3 огляду на зазначені складові системи, необхідно визначити та охарактеризувати чинники, які впливають на рівень інформаційного забезпечення, а саме зовнішні (коло зовнішніх користувачів; рівень розкриття інформації для задоволення інформаційних потреб зовнішніх користувачів) та внутрішні (розміри підприємства та масштаб діяльності; структура управлінського апарату; інформаційні потреби користувачів; кваліфікаційний рівень працівників облікового і аналітичного підрозділів; рівень деталізації та узагальнення інформації; періодичність подання інформації). Доцільним вбачається проаналізувати вплив окремих із зазначених чинників на формування обсягів інформаційного забезпечення. Розміри підприємства та масштаб діяльності впливають на організацію структурних елементів системи управління, необхідність інформаційного забезпечення для проведення аналізу та контролю. Розширення масштабів діяльності вимагає створення додаткових елементів у системі управління, розгалужену структуру каналів надання й отримання економічної інформації та збільшення обсягів вхідної та вихідної облікової і аналітичної інформації. Інформаційні потреби користувачів мають прямий вплив, адже для кожного окремого користувача внутрішнього й зовнішнього середовища необхідно чітко визначити обсяги та види обліково-аналітичної інформації, рівень ії узагальнення й форму подання. На проведення відповідних облікових і аналітичних процедур для підготовки управлінської інформації слід попередньо здійснювати розрахунки витрат часу, кількості працівників та враховувати рівень їх кваліфікації.

Компоненти фінансової звітності відображають різні аспекти господарських операцій і подій за звітний період, відповідну інформацію попереднього звітного періоду та розкриття облікової політики та їі змінах, що робить можливим ретроспективний та перспективний аналіз діяльності підприємства для подальшого прийняття управлінських рішень (табл. 1).

Таблиця 1.

Призначення основних компонентів фінансової звітності

\begin{tabular}{|c|c|c|c|}
\hline № & $\begin{array}{l}\text { Компонент } \\
\text { фінансової } \\
\text { звітності }\end{array}$ & Зміст & Використання інформації \\
\hline 1 & $\begin{array}{l}\text { Баланс } \\
\text { підприємства (Звіт } \\
\text { про фінансовий } \\
\text { стан) }\end{array}$ & $\begin{array}{l}\text { Наявність економічних ресурсів, які } \\
\text { контролюються підприємствами на } \\
\text { дату балансу. }\end{array}$ & $\begin{array}{l}\text { Оцінка структури ресурсів підприємства, } \\
\text { їх ліквідності та платоспроможності } \\
\text { підприємства; прогнозування майбутніх } \\
\text { потреб у позиках; оцінка та прогнозування } \\
\text { змін в економічних ресурсах, які } \\
\text { підприємство, контролюватиме в } \\
\text { майбутньому }\end{array}$ \\
\hline 2 & $\begin{array}{l}\text { Звіт про фінансові } \\
\text { результати (Звіт } \\
\text { про сукупний } \\
\text { дохід) }\end{array}$ & $\begin{array}{l}\text { Доходи, витрати і фінансові } \\
\text { результати діяльності підприємства } \\
\text { за звітній період. }\end{array}$ & $\begin{array}{l}\text { Оцінка та прогноз прибутковості } \\
\text { діяльності підприємства; структури } \\
\text { доходів та витрат. }\end{array}$ \\
\hline 3 & $\begin{array}{l}\text { Звіт про власний } \\
\text { капітал }\end{array}$ & $\begin{array}{l}\text { Зміни у складі власного капіталу } \\
\text { підприємства протягом звітного } \\
\text { періоду. }\end{array}$ & $\begin{array}{l}\text { Оцінка та прогноз змін у власному } \\
\text { капіталі. }\end{array}$ \\
\hline 4 & $\begin{array}{l}\text { Звіт про рух } \\
\text { грошових коштів }\end{array}$ & $\begin{array}{l}\text { Генерування та використання } \\
\text { грошових коштів протягом звітного } \\
\text { періоду. }\end{array}$ & $\begin{array}{l}\text { Оцінка та прогноз операційної, } \\
\text { інвестиційної та фінансової діяльності } \\
\text { підприємства. }\end{array}$ \\
\hline 5 & $\begin{array}{l}\text { Примітки до } \\
\text { річної фінансової } \\
\text { звітності }\end{array}$ & $\begin{array}{l}\text { Обрана облікова політика. } \\
\text { Інформація, не наведена } \\
\text { безпосередньо у фінансових звітах, } \\
\text { але обов’язкова за П(С)БО. } \\
\text { Додатковий аналіз статей звітності, } \\
\text { необхідний для забезпечення їі } \\
\text { зрозумілості. }\end{array}$ & $\begin{array}{l}\text { Оцінка та прогноз облікової політики; } \\
\text { ризиків або невпевненості, які впливають } \\
\text { на підприємство, його ресурси та } \\
\text { зобов'язання; діяльності підрозділів } \\
\text { підприємства, тощо. }\end{array}$ \\
\hline
\end{tabular}

Таким чином, для ефективного аналізу фінансової звітності необхідно уникати проблем, що пов'язані 3 тлумаченням термінів та інших носіїв фінансової інформації, що використовується при прийнятті рішень усіма зацікавленими сторонами.

Висновки. Основна інформація про фінансовий стан, власний капітал, фінансові результати, рух грошових коштів та інші показники зосереджена у чотирьох формах фінансової звітності та у їі примітках, які 
були проаналізовані у даній роботі. Для прийняття вигідних економічних рішень, а також для ефективного управління фінансами, підприємство повинно таким чином складати форми фінансової звітності, щоб вони дали змогу оцінити, проаналізувати фінансовий стан підприємства, результати його діяльності та рух грошових коштів за звітний період, та планувати фінансову політику підприємства на майбутнє, та здійснювати управління фінансами підприємства так, щоб отримати більший прибуток, ніж був за попередній період.

\section{Список літератури.}

1. Біла Л.М. Формування системи фінансової звітності сільськогосподарських підприємств : автореф. дис. на здобуття наук. ст. к.е.н. за спеціальністю 08.06.04 Бухгалтерський облік, аналіз та аудит. Київ, 2005.20 с.

2. Закон України «Про бухгалтерський облік і фінансову звітність в Україні», прийнятий Верховною Радою України від 16.07.1999 p. No996-XIV (Редакція від 03.01.2017). URL: http://zakon4.rada.gov.ua/laws/show/996-14.

3. Семенишена, Н.В. Комунікативна та інформаційно-аналітична функції бухгалтерської звітності сільськогосподарських підприємств: автореф. дис. на здобуття наук. ступеня канд. екон. наук: спец. 08.00.09 «Бухгалтерський облік, аналіз та аудит (за видами економічної діяльності)». Національний науковий центр «Ін-т аграр. економіки». Київ. 2008. 20-21 с.

4. Семенишена Ю.О. Аудит в Україні: сучасний стан та перспективи розвитку. Бухгалтерський облік, аналіз і аудит в управлінні економічними процесами в світовій і національній економіці: сучасний стан та перспективи : матеріали міжнар. наук.-практ. конф. 11 грудня 2015 р. (ПДАТУ, м. Кам'янець-Подільський). Тернопіль : Крок, 2015. С. 142-145.

5. Національне положення (стандарт) бухгалтерського обліку 1 «Загальні вимоги до фінансової звітності», Наказ Міністерства фінансів України 07 лютого 2013 року № 73 (Редакція від 14.03.2017). URL: http://zakon2.rada.gov.ua/laws/show/z0336-13.

\section{References.}

1. Bila, L.M. (2005), "Formation of the system of financial reporting of agricultural enterprises", Ph.D. Thesis, Accounting, analysis and audit, Kyiv,Ukraine.

2. Verkhovna Rada of Ukraine (2017), The Law of Ukraine "Accounting and financial reporting in Ukraine", available at: http://zakon4.rada.gov.ua/laws/show/996-14 (Accessed 01 Nov 2019).

3. Semenyshena, N.V. (2008), "Communicative and information-analytical functions of accounting of agricultural enterprises”, Ph.D. Thesis, Accounting, analysis and audit, Kyiv,Ukraine.

4. Semenyshena, Yu.O. (2015), “Audit in Ukraine: current state and prospects for development”, Bukhhalters'kyj oblik, analiz i audyt v upravlinni ekonomichnymy protsesamy v svitovij i natsional'nij ekonomitsi: suchasnyj stan ta perspektyvy : materialy mizhnarodnoi naukovo-praktychnoi konferentsii [Accounting, analysis and audit in the management of economic processes in the world and national economy: current state and prospects: materials of the international scientific-practical conference], Krok, Ternopil, Ukraine, 11 December, pp. 142-145.

5. Ministry of Finance of Ukraine (2013), Order "National Accounting Standard (Standard) 1 General Financial Reporting Requirements", available at: http://zakon2.rada.gov.ua/laws/show/z0336-13 (Accessed 05 Nov 2019). 